\title{
Descriptive Analysis of the Profiles of Orphanage Children to Entrepreneurship in Indonesia
}

\author{
Sopiah Sangadji \\ Faculty of Economics, Sate University of Malang \\ Heny Kusdiyanti \\ Faculty of Economics, State University of Malang \\ Rosanti Rosmawati \\ Faculty of Engineering, State University of Malang \\ URL: http://dx.doi.org/10.5296/ijld.v4i1.5027
}

Doi:10.5296/ijld.v4i1.5027

\begin{abstract}
This study is intended to : (1) Identify the characteristics of orphanage children in Malang, (2) Identify the real needs of the orphanage children. The population of this study is the orphanage children throughout Malang namely 8,846 children. With purposive sampling, it was collected 100 orphans who are taking high school education or equivalent. The data collection techniques used are questionnaires, interviews and observations. Data analysis applied descriptive statistics. From the results of the study there is conclusion : (1) The gender majority of the orphanage children is male; the majority of them have no mother, only have father; majority of orphanage children come from towns/regencies in East Java; the whole orphanage children as research subjects are the ones who are studying SMTA/SMK/MA. (2) The majority of the orphanage children have not joined entrepreneurship training; majority of orphanage children want/require entrepreneurial training, business design and practical accounting; majority of orphanage children are sure that by joining the training, they will increase entrepreneurial knowledge and skills, the entrepreneurial spirit will grow.
\end{abstract}

Keywords : Entrepreneurship Training, Orphanage Children

\section{Introduction}

In the Act of 1945 stated that the poor and abandoned children maintained by the state. However in reality the state's ability to maintain the poor and neglected children are still very limited, so there must be a participation of public and social - religious organizations in overcoming the problems the poor and the neglected children. One of the institutions that up to now remained consistently assist the government in maintaining, caring and even schooling the poor and neglected children are orphanage institutions. In early development, the establishment of an orphanage aims to help reducing the problem of orphans and abandoned children from poor families by providing the needed assistance all in. The service approach used by orphanage tends to show an strong approach of caricature philanthropy.

Paradigm shift in nowadays social welfare has opened more space for people to participate in community development in the handling of social welfare issues in general. One resulted implication is the development of civil society organizations engaged in community service in order to improve the social welfare. The condition provide a logical consequence for the social service agencies to immediately arrange service system and improve the competence of this institution. This is important to do, because paradigm changes of social services requires each service agency including orphanages to provide a more rational approach by promoting professional services. Thus, the challenge that must be faced forward by orphanage is the 
function of the development itself, no longer has function as a caricature of a service institution, but it should be an institution that is able to be great training center, which is able to provide excellent service to the target children leading to empowered and self-sufficient children after they are no longer in the care of the orphanage.

In managing the orphanage institution, managers have to choose the right approach model to achieve the main objective namely the existence of orphanage institution as an agency empowering poor children. In general, according to Syamsul (2005) there are four common approaches to empower clients in orphanages: (1) Socio-caricature approach. The approach of socio-caricature is the service approach based on an assumption that the fostered clients are the community of helpless, suffering, the poor orphanage who are not able to solve their own problems. Therefore orphanage placed itself as an institution that will help, support and take pity and contribute based on human values (caricature philanthropy) and Islamic values. (2) Economic Approach. Socio-Economic approach is a form of service approach that is based on the understanding that improving the welfare of fostered children / clients in the orphanage will only be realized, if provided access to the material (economic) such as capital adequacy, provision of education costs, health costs and so forth, which is fundamentally be a requirement. Being economical activities of the service approach is generally done in the form of business development economically productive clients when completed is expected to be funded schools and institutions, then he will be educated to live independently to build his family. (3) Transformative Approach. Transformative approach is a form of service that the approach in the belief that the handling of abandoned children and orphans is the change in the views, thoughts, attitudes and behavior together toward personal independence. The values developed in this approach is that humans essentially have the freedom to choose the way of life and determine his future. Additionally human beings have dignity and potential that can be developed, so it can be a fundamental factor to change his fate. The performance of this approach in general activity directed at efforts to develop a critical consciousness that can stimulate the transformation of the value of life. (4) Holistic Approach. Holistic approach is a service approach that has confidence that efforts to improve the welfare client orphanage not only enough to provide material assets (economic) and the caricature done. However, a holistic approach must also be integrated economically with the caricature of the transformative approach.

In line with the models proposed by Syamsul approach (2005) on a particular model of transformative approach it is essential for the development of research needs to be conducted to empower orphans in particular that will pass SMTA so that, when he left school and had to leave the orphanage he already has certain skills in the business so that he can be independent in managing the business to finance his life. Given the average ability to fund orphanages and poor children abandoned education only up to the SMTA, while to finance up to the college level many homes are not financially able. Experience has shown when a foster care homes are not well prepared to be able to live independently in the community through the ability to master certain business skills then they will be unemployment. In fact most of them will return to the street children that would make them have no future. Therefore, it is necessary for all parties, including the role of universities to help prepare children for the orphanage to early to be ready to live in the community.

Malang as the second largest city in East Java today handling problems faced by the poor and neglected children. In 2011 the author observed results are poor and neglected children fostered by the orphanage institutions in Malang is as follows: The number of children fostered in orphanages in the district area Lowokwaru is 3,384 children, 1,899 children fostered in Kedungkandang district, 1,979 children fostered in Klojen district, in Sukun district fostered 1,238 children and as many as 406 children Blimbing districts. Thus the number of children in foster care as a whole is as much as 8,846 children. While the number of 
orphanage institution in Lowokwaru is 15 buildings, Kedungkandang is 9, Klojen is 10, Sukun is 11, and Blimbing is 14. (www.malangkota.go.id, 2011). Children who are fostered by the orphanage in addition consists of orphans or the poor, most of them are children with problems. Those children with problems here because they have lost their parents when still little children so that they lose the figures may provide role models to be emulated. System of norms which they applied is also not good, either religious norms and social norms, they often do something viewed from the eyes of the general norm is wrong but for them is not a mistake. For instance smoking, not praying, absent from school, took another belongings etc. They never think of the future. Therefore, they do require a touch of outside parties to assist orphanages to change their way of thinking, the need for transformation system of values and norms that they applied includes equipping the orphanage coaches to be able to hold the transformation of the value system adopted by orphanage children.

\section{Theoretical Background}

\section{The concept of Community Empowerment}

Community empowerment is a concept that summarizes the economic development of social values. This concept reflects the new development paradigm, namely the characteristics of "people-centered, participatory, empowering, and sustainable" (Chambers, 2005). This concept is broader than merely meet the basic needs (basic needs) or provide a mechanism to prevent further impoverishment (safety net), which is a lot of thinking lately developed as an effort to find an alternative to the empowerment of the community. In that frame of mind, efforts to empower communities can be viewed from three angles. First, creating an atmosphere or climate that allows the potential for developing communities (enabling). Here the starting point is the recognition that every human being, every society, has the potential to be developed. That is, there is no society at all without power, because in that case would be already extinct. Empowerment is an attempt to build the power, by encouraging motivating and raising awareness of their potential and strive to develop it. Second, strengthening the potential or power held by the public (empowering ). In this attempt, it requires more positive steps, apart from just creating a climate and atmosphere. The strengthening includes concrete steps, and involves the provision of various inputs, and the opening of access to the various opportunities that would make people become more empowered . In order to empower this, very basic effort is to increase the education level and health status, as well as access to the sources of economic growth such as capital, technology, information, employment, and markets. Input of the availability of funding agencies, training, and marketing in the surrounding communities are empowered. For that, there needs to be a special program for people who are less powerful, because of the common programs that apply to all, not always able to reach specific segments of society such as orphans. Empowerment not only includes the strengthening of individual members of society, but also institution - the management. Instilling the values of modern culture such as hard work, thrift, transparency, and the responsibilities is the principal part of this empowerment. In the process of empowerment, there must be a prevention to weaken the weaker side, because in the face of strong under-empowerment. Therefore, protection and weak side with the very fundamental nature of the concept of community empowerment. Protection does not mean isolating or covering of interaction, because it would likely dwarf the small and weakening. Protecting should be seen as an attempt to prevent an unbalanced competition, as well as the exploitation of the strong over the weak. Community empowerment is not to make people become increasingly dependent on a variety of programs giving (charity). Because, basically what is enjoyed, must be produced it themselves (the results of which can be exchanged with other parties). Thus, the ultimate goal is self-empowerment society, enable and develop the ability to advance themselves toward a better life is continuous. 


\section{The Measurements of Community Empowerment Success}

To find out how far community empowerment has been successful, there needs to be monitoring and targeting, as far as possible that can be measured to be compared. How to measure it has evolved, such as among others, have called upon the Gini index, the number of people living below the poverty line, the number of rural poor, the role of small industries, agriculture exchange rates, minimum wages and so on. Quality of human development is not only about the economic aspect, but also the other side, namely education and other aspects. It is also being developed by Bappenas with BPS sort of numbers people's welfare index that combines indicators of economic, health, and education into a numeric index (Harry Hikmat , 2008). In the international index of welfare of this kind has been developed by UNDP, known as the Human Development Index (HDI) as mentioned above. Humans also have to prepare for eternal life through spiritual development, as part of community development, in order to build a moral society .

\section{Community Empowerment Strategies}

\section{in the Context of Economic Development of the People}

According to Chambers (2006 ) in order to strengthen the position and role of the people's economy in the national economy of a country strived to accelerate structural changes (structural adjustment or structural transformation). These include the structural transformation process of change from a traditional economy to a modern economy, from a weak economy that is resilient to the economy, from subsistence economy to a market economy, from dependence to independence. Several steps must be taken to develop a strategic economic empowerment of the people through by Kwik Kian Gie (2000). First, an increase in access to productive assets (productive assets). Second, strengthen the position of business transactions and partnerships economy. As a manufacturer and seller, the position and strength of the people in the economy is very weak. They are price takers because their numbers are very much with the market share of each of which are very small. Thus, the main strategy of empowerment that needs to be carried out simultaneously are: (1) community empowerment, include: (a) The establishment of democracy and public participation at the national level to the village, to be the value that is inherent in every action in community development programs; democracy allows widening the meaning of the problems of the bottom layer to the elite of society, (b) Decentralization and autonomy in decision-making so that the problem and the solution has a strong empirical roots. This increases the effectiveness and efficiency in the development of problem-solving efforts, (c) Increasing the ability of central and local government in serving the needs of the poor and marginalized, (d) Sustainability of the program or project to facilitate the movement of people in maintaining or improving the outcomes of programs and projects, (e) Provision of a facilitator to move the group life and local communities, and provide managerial knowledge; facilitator also serves as a mediator to allow the communication equivalent of the poor and marginalized to the other party so that the poor access to wide open. (2) Expansion of opportunity, include: (a) preparation of public policies in the economic, political, social, and cultural allocated to poor and marginal layer, (b) Development of physical infrastructure in the fields of transport, communications, housing, health care, especially for the lagging regions; development physical directed to improve and accelerate the acquisition impact to the economic development of the region, (c) Providing access to educational, economic, social institutions, political institutions, cultural institutions, especially to poor families and groups of women, thereby undercoat and marginalized groups have capital for competition in modern life (3) Development of social protection (enhancing social security), including: (a) Provision of legality to the property of the poor to be used as working capital and acquisition micro/small loans (b) The establishment or 
strengthening of a group or organization in a modern so that the poor can benefit from access to economic, political, social and cultural improvement of social resilience and well-being of the community, (c) Construction of a network of cooperation between individuals, organizations/community based organizations, government agencies, and economic institutions; networks are useful for extending the limits of the individual or groups, as well as the defense of a crisis that may confront in a sudden.

\section{Complementary Role in The Community Empowerment}

Poor people generally have limitations in developing theirselves. Therefore, it is necessary companion to guide the poor in an effort to improve their welfare. Companion charge of accompanying the formation and organization of community groups as a facilitator, communicator, or dynamist. The scope of the guidance counselors do include efforts to improve the quality of human resources, the quality of the members and leaders of the group as well as an increased ability to member businesses. For this purpose, the companion needs to know and conduct intensive communication with the group. According to Harry Hikmat (2003) the most effective companion of the members of the community itself, ie members of the public who have a more prosperous and have been successful in life and economic activity. Also, it can also be recruited graduates from college to be a companion. To be able to perform their duties effectively, the companion must be ready to work at any time, attend group meetings, organizing training programs, as well as assist the group in gaining access to services needed. Mentoring is actually identical to the extension (Slamet, 2002). Regarding the philosophy of education, Agpalo (2006) mentions five points filosolfi extension namely (1) the importance of the individual (2) through the process of educating (3) democratic process (4) collaboration and (5) sustainable. As mentioned earlier, in Agpalo Kelsey and Hearne (2006 ) and Bryant in Agpalo (2003) calls the philosophy of counseling / mentoring is "selfhelp" by helping people to help themeselves. When developed, philosophical counseling in community development is SELP help and mutual help .

Operationally escort duties in the field are trying to actualize the potential that is still stored in the public meeting by way of "fishing" so that the potential of the community through a hidden revolution can be actualized. The presence of a companion who had the support of institutions that are specifically foster empowerment group in accordance with the potential and the possibilities that there will be local to achieve the expected results if identified or understood the factors that affect the implementation of self-help groups. The third factor that must be recognized and understood by the companion of which are (1) internal factors group, the factors comprising members of the sub-factor, sub-factor board, sub-factors and sub-factors activity mechanism of action (2) external factors, namely sub socioeconomic factors, sub-factors relationships with local government officials or agencies, and sub-factors of government programs aimed at developing region where the self-help groups exist (3) development of institutional factors that include sub-factors the agency insight, a sub-factor development institutions and organizations sub-factors available energy in the development of the institution (lsmawan and Budiyrantora, 2005). In a companion mentoring group must have ethics as development practitioners, concerning what should be done and what should not be done in mentoring activities: (1) What should be done is: Empathy, Cherish, Familiar, Equality, Courtesy, Humorous, Openness, Sharpening foster compassionate, a Good listener, Empathetic, Cheers, Tolerance, Equal opportunities, Encouraging, Learning from others, Mutual trust, Sharing experiences and knowledge, Mutually supportive, Humble (2) What should not be done by a companion include: Feeling better know, patronizing, overbearing, convict, a rrogant, criticize, suspicion, bossy, talk with profane language, haste, monopolize, angry, 
controlling, like mock, underestimate, and discrediting, partial, do not want cooperation, requesting remuneration, ask appreciated, lying and cheating (Source PRA Simulation Results for the District Social Officer "PSK" (BKSN, 2000)

\section{THE METHOD OF STUDY}

\section{A. Type and Variables of Research}

\section{Type of Research}

Based on the title and description of the background research that has been stated earlier, this study is classified as a development research, where this research was to develop a model of entrepreneurial training and mentoring to empower orphanage children throughout Malang.

2. Research variables

Since this study is the development, the study is a single variable, namely the development of a model of entrepreneurship training and mentoring to empower orphanage children throughout Malang

3. Population and sample of study

The population was orphanage children throughout Malang, can be explained in detail the amount of total study population is as follows: In the region of Lowokwaru there are 3,384 children in the district center of information enclosure 1,899 children, as many as 1,979 children Klojen districts, in Sukun there are 1,238 children, and 406 children in Blimbing districts. Thus the number of children in foster care as a whole is as much as 8,846 children. At this early stage deliberately taken 100 orphans who are studying at the high school level / SMK / MA were selected as sample (purposive sampling).

\section{B. Data Collection and Research Instruments}

The methods of data collection and the use of the instrument in this study can be described as follows :

1. Methods : Questionnaires. Questionnaire was used to collect data on : the analysis of the situation, the characteristics of the respondents, the data on the real needs of the respondents.

2. Interview method. To complement the data that has been captured through the questionnaire method also conducted interviews with respondents, as well as related parties.

3. Observation method. In this method the researcher to look closely on the activities of the orphanage children throughout Malang.

4. Methods literature. A literature study to find references about training models ever developed by experts or other researchers. After that, through the process of comparing the model which is suitable then modified and adapted to the needs and characteristics of the respondent is developed models of entrepreneurship training and mentoring for coconut farmers.

\section{Data Analysis}

The data analysis was done by descriptive statistical analysis. Statistical analysis was used to answer the following questions:

1. Identify the characteristics of the children in the orphanage Malang

2. Identify the real needs of the orphanage children 


\section{Macrothink $\Lambda$ Institute}

\section{THE RESULTS OF STUDY}

\section{Descriptive Analysis About the Characteristics of Respondents.}

\subsection{Demographic Description of Respondents}

After going through the selection process of the obtained 100 eligible participants with established. Subsequently presented below about the description consisted of demographic, gender, family background of the respondents, respondents' level of education, gender, area of origin of the respondent, the respondent's age and participation in education and training, and understanding of entrepreneurship and understanding of the business plan .

Table 4.1. The Gender of Respondent

\begin{tabular}{|c|c|c|c|}
\hline No & Description & Total & $\%$ \\
\hline 1 & Male & 77 & 77 \\
\hline 2 & Female & 23 & 23 \\
\hline & Total & 100 & $100 \%$ \\
\hline
\end{tabular}

Source: Primary Data processed (August, 2013)

From the table above, note the number of respondents were male 77 people and women 23 . This means that until now orphanage in the city of Malang was much more accommodating male children.

Table 4.2. Family Background

\begin{tabular}{|l|l|c|c|}
\hline No & Description & Total & $\%$ \\
\hline 1 & The status of orphanage children have no father & 53 & 53 \\
\hline 2 & The status of orphanage children have no mother & 29 & 29 \\
\hline 3 & $\begin{array}{l}\text { The status of orphanage children have no father } \\
\text { and mother }\end{array}$ & 18 & 18 \\
\hline & Total & 100 & 100 \\
\hline
\end{tabular}

Source: Primary Data processed (August, 2013)

From the above table, orphanage children have only father is 53 or $53 \%$, have only mother is 29 children or $29 \%$, whereas the orphan status or who do not have a father and mother are is 18 children, or $18 \%$. This means a much needed external help to empower them so that one day when out of the orphanage they can be more independent.

Table 4.3. The Place of Origin of Respondent

\begin{tabular}{|l|l|c|c|}
\hline No & Description & Total & $\%$ \\
\hline 1 & Around Malang & 54 & 54 \\
\hline 2 & Around East Java & 12 & 12 \\
\hline 3 & In Java & 9 & 9 \\
\hline 4 & Out of Java & 25 & 25 \\
\hline & Total & 100 & 100 \\
\hline
\end{tabular}

Source: Primary Data processed (August, 2013)

From the above data, it was found out that there are orphans in orphanages Malang was the place of origin vary, not only from the city of Malang. From Malang city around 54 people, or $54 \%$, East Java around 12 people or $12 \%$ of the outer east Java as much as 9 or $9 \%$ and from outside Java, especially from Eastern Indonesia as many as 25 people, or $25 \%$. 
Table 4.4. Level of Education of Respondent

\begin{tabular}{|l|l|c|c|}
\hline No & Description & Total & $\%$ \\
\hline 1 & SD/ Elementary & - & - \\
\hline 2 & SMP/ Junior High School & - & - \\
\hline 3 & $\begin{array}{l}\text { SMA/SMK/MA/ Senior High } \\
\text { School }\end{array}$ & 100 & 100 \\
\hline 4 & PT / College & - & - \\
\hline & Total & 100 & 100 \\
\hline
\end{tabular}

Source: Primary Data processed (August, 2013)

From the table above, it was found out the level of education of orphanage children is SMTA/SMK/MA, because the orphanage is only intended for children SMTA level.

Table 4.5. Have Joined Enterpreneurship Education and Training

\begin{tabular}{|l|l|c|c|}
\hline No & Description & Total & $\%$ \\
\hline 1 & Yes & 25 & $25 \%$ \\
\hline 2 & No & 75 & $75 \%$ \\
\hline & Total & 100 & 100 \\
\hline
\end{tabular}

Source: Primary Data processed (August, 2013)

From the table above it can be seen that, orphans were largely not had the education and entrepreneurship training which is about 75 people, or $75 \%$, while the already trained about 25 people, or $25 \%$.

\section{Descriptive Analysis of the Respondents' Real Needs}

In the analysis of the real needs of respondents, the researchers tried to dig up information from respondents about their real needs of an ideal education and training to improve their skills in the field of entrepreneurship. Coverage of information about the real needs of participants who explored which include: Level of respondents about the need for education and training, respondents belief that if he followed the education and training that will improve the ability, willingness to participate in education and entrepreneurship training. For more details about the analysis of the real needs of the respondents about the importance of entrepreneurship training can be described below.

Table 4.5. Respondents' Need Level on Knowledge of entrepreneurship

\begin{tabular}{|l|l|c|c|}
\hline No & Description & Total & $\%$ \\
\hline 1 & Desperate need & 85 & 85 \\
\hline 2 & Need & 15 & 15 \\
\hline 3 & Fairly need & - & - \\
\hline 4 & Need less & - & - \\
\hline & Total & 100 & 100 \\
\hline
\end{tabular}

Source: Primary Data processed (August, 2013)

From the table above it can be seen the number of respondents who stated in desperate need of knowledge entrepreneurship are as many as 85 people, or $85 \%$, which need is 15 people, or $15 \%$. 
Table 4.6. Respondents' Need Level on Entrepreneurship Education and Training

\begin{tabular}{|l|l|c|c|}
\hline No & Description & Total & $\%$ \\
\hline 1 & Desperate need & 100 & 100 \\
\hline 2 & Need & - & - \\
\hline 3 & Fairly need & - & - \\
\hline 4 & Need less & - & - \\
\hline & Total & 100 & 100 \\
\hline
\end{tabular}

Source: Primary Data processed (August, 2013)

From the table above, it is found out all states orphanage is in desperate need of education and training for entrepreneurship is 100 people or $100 \%$ thus entrepreneurship training for orphans has become important to be implemented. To prepare for the future when they have graduated from high school SMTA and is no longer live within the orphanage institution.

Table 4.7. Respondents' Need Level on Business Design Knowledge

\begin{tabular}{|l|l|c|c|}
\hline No & Description & Total & $\%$ \\
\hline 1 & Desperate need & 74 & 74 \\
\hline 2 & Need & 26 & 26 \\
\hline 3 & Fairly need & - & - \\
\hline 4 & Need less & - & - \\
\hline & Total & 100 & 100 \\
\hline
\end{tabular}

Source: Primary Data processed (August, 2013)

From the table above, it is found out the respondents expressing deeply need knowledge of the business design is 74 or $74 \%$ and who expressing need is 26 people or $26 \%$.

Table 4.8. The Belief that Joining Entrepreneurship Training Can Improve Entrepreneurship Ability

\begin{tabular}{|l|l|c|c|}
\hline No & Description & Total & $\%$ \\
\hline 1 & Believe deeply & 72 & 72 \\
\hline 2 & Believe & 28 & 28 \\
\hline 3 & Fairly believe & - & - \\
\hline 4 & Believe less & - & - \\
\hline & Total & 100 & 100 \\
\hline
\end{tabular}

Source: Primary Data processed (August, 2013)

From the table above, it is found out that respondents believe deeply that joining the entrepreneurship education and training may improve the ability of entrepreneurship is 72 or $72 \%$, and the number the ones who believeis 28 people or $28 \%$. 
Table 4.9. The Belief That After Attending Business Design Training Materials May Improve Business Design Ability

\begin{tabular}{|l|l|c|c|}
\hline No & Description & Total & $\%$ \\
\hline 1 & Believe deeply & 95 & 95 \\
\hline 2 & Believe & 5 & 5 \\
\hline 3 & Fairly believe & - & - \\
\hline 4 & Believe less & - & - \\
\hline & Total & 100 & 100 \\
\hline
\end{tabular}

Source: Primary Data processed (August, 2013)

From the table above, it is found out that approximately 95 respondents or $95 \%$ said believe deeply that attending business design training may improve entrepreneurship ability, while those who believe is 5 or $5 \%$.

Tabel 4.10. The Readiness in Attending Post-Training Bussiness Consultation

\begin{tabular}{|l|l|c|c|}
\hline No & Description & Total & $\%$ \\
\hline 1 & Ready very much & 100 & 100 \\
\hline 2 & Ready & - & - \\
\hline 3 & Fairly ready & - & - \\
\hline 4 & Less ready & - & - \\
\hline & Total & 100 & 100 \\
\hline
\end{tabular}

Source: Primary Data processed (August, 2013)

From the table above, it is found out that the respondents are also very excited to attend the post-training business consultation. This business consultation includes a business plan, how to start opening a business, how dealing with supplier, how the policy of pricing, how to promote, how to deal with banks etc. The naumber who have great willing is 100 people, or $100 \%$.

Tabel 4.11. The Readiness in Attending Practical Accounting Training

\begin{tabular}{|l|l|c|c|}
\hline No & Description & Total & $\%$ \\
\hline 1 & Ready very much & 100 & 100 \\
\hline 2 & Ready & - & - \\
\hline 3 & Fairly ready & - & - \\
\hline 4 & Less ready & - & - \\
\hline & Total & 100 & 100 \\
\hline
\end{tabular}

Source: Primary Data processed (August, 2013)

From the table above, it is found out that the respondents were very willing to attend the practical accounting training. They who stated very willing is 100 people, or $100 \%$. Practical knowledge of accounting is important since in the future they can record their efforts to develop their business transactions, and can make clear and simple financial statements.

\section{DISCUSSION}

From the result of study in term of descriptive data presentation on characteristics and the real needs of the respondents, it can be discussed the following matters:

\section{Characteristics of Respondents}


From the descriptive analysis, it is found out that respondents with male gender are 77 persons and female are 23 persons. This means that until now orphanage in the city of Malang that accommodate more boys. It is also known that orphanage children who have just father is 53 or $53 \%$, of which only have mother is 29 children or $29 \%$, whereas the orphan status or who do not have a father and mother is 18 children, or $18 \%$. This means need much external help to empower them so that one day when they are out of the orphanage they can be more independent. Besides, in fact the orphans in the orphanage Malang have various place of origin, not only from Malang. From Malang city is 54 people or $54 \%$, East Java is around 12 people or $12 \%$ and from outside East Java is 9 or $9 \%$ and from outside Java especially from Eastern Indonesia is 25 people or $25 \%$. The level of education of orphanage children is SMTA/SMK/MA level, because the orphanage is only intended for SMTA level children, were most of orphanage children having no education and training for entrepreneurship is about 75 people or $75 \%$, while the already attended training about 25 people or $25 \%$.

From these data it is known that most of the orphanage are the ones do not have a father, orphans or have no mother and there is even an orphan that has no father and mother. Whereas the orphanage ability to educate and nurture them only a high school (SMTA) level, thus need to be prepared entrepreneurial training models to prepare them to be independent in the community. If noticed from the aspect of the place of origin of the orphans is not derived from Malang city but also includes areas outside of Malang, even outside the province of East Java, as of Nusa Tenggara Timur (NTT), from Maluku and Nusa Tenggara Barat. Most of the orphans are male and the average number of them did not had the entrepreneurial education and training to sustain their lives when out of the orphanage environment.

Noticing this condition therefore it needs the intervention of outsiders either from the government or other institutions such as universities, to be able to break the chain of poverty experienced by these children. Should be objectively admitted that they fostered in this orphanage come from average families who can not afford, therefore it is very necessary to have an effort to empower these children so that they do not get caught kept in conditions of poverty. Because one of the unresolved issues in this country is the problem of poverty. Poverty that ensnared Indonesian society is like an incurable chronic disease if not treated immediately. Meanwhile, the government's efforts in poverty alleviation is not maximized. It can be seen from the posture of the government budget in 2011, in which total state spending has reached Rp. 1,320 trillion, with details of expenditure is Rp 908.3 trillion, the central government and the regional transfer of Rp 412.5 trillion. From Rp 908.3 trillion of central government, $\mathrm{Rp} 182,9$ trillion or approximately $20.14 \%$ allocated to personnel, Rp142, 8 trillion or in other words approximately $15.73 \%$ is allocated only for goods. Rp 106.6 trillion or approximately $11.74 \%$ is allocated to pay interest on the debt and Rp 195.3 trillion or approximately $21.5 \%$ to cover fuel and electricity subsidies. Meanwhile, capital expenditure in the form of infrastructure development only Rp140, 9 trillion or approximately $15.51 \%$ and social assistance expenditures that directly touch the poor people only accounted for approximately $9.01 \%$, equivalent to Rp 81.8 trillion. According to Kemal A. Stamboel (2012) subsequently tried to offer an important concept of poverty alleviation efforts. Poverty is a worldwide phenomenon. Each country has a poverty characteristic of each that can be caused by many reasons such as geography, culture, government systems, and others. As an agricultural island, poverty in Indonesia also have certain characteristics. In sector term, the number of poor people in Indonesia is concentrated in agriculture sectors. This sector from the past until now has always been the place where the majority of poor households rely their lives on. The data of BPS (2010) found that approximately $63 \%$ of farm workers, about $6 \%$ worked in the industrial sector, about $10 \%$ have not yet or do not have jobs, and the remaining $21 \%$ work in other sectors. The size dependence of the poor on the agricultural sector to make this 
important sector to get priority in poverty reduction efforts. While the study of education, Indonesian society is still experiencing a disheartening fate. The percentage number of the population living in households with household heads who did not complete nine years of basic education reached $83.65 \%$ to $50.47 \%$ for rural and urban areas. Furthermore, the most concern is the low level of education of young people who could be seen from the percentage of the population aged 18-24 years who did not complete the nine-year basic education amounted to $40.70 \%$ and $15.97 \%$ in rural areas to urban areas. One strategy to get out of this poverty is the orphanage children should be given entrepreneurial training in any field. Such as the automotive, computer, mobile phones, fish farming, vegetable cultivation, etc., in order for them to live more independently facing the future ahead. Thus, when a child is nurtured in the orphanage environment it is not enough only in the formal school only but also need to be equipped with knowledge about life (life skills) so that he can survive in the future.

\section{Respondents' Real Needs}

From the descriptive analysis above it can be seen that the number of respondents expressed deeply need knowledge of entrepreneurship are 85 people or $85 \%$, which need are 15 people or $15 \%$. Orphanage children also expressed highly in need of entrepreneurship education and training is 100 people or $100 \%$ thus entrepreneurship training for orphans is important to implement. To prepare for the future when they have graduated from high school (SMTA) and had not lived anymore within the orphanage. It is found that the respondents who stated need deeply business design knowledge is 74 or $74 \%$ and the stated need is 26 people or $26 \%$. On the other hand respondents feel believe so much that by attending the entrepreneurship education and training will improve their entrepreneurship ability is 72 or 72 $\%$, and the ones who believe is 28 or $28 \%$. The respondents also stated that approximately 95 respondents or $95 \%$ said believe so much that attending business design training can improve their entrepreneurship ability, while those who believe is 5 or $5 \%$. After the training of the respondents also expressed eager to follow the post-training business consultation. This business consultation includes a business design, how to start opening a business, how dealing with supplier, how the policy of pricing, how to promote, how to deal with banks etc. They who very ready are 100 people or $100 \%$. Besides, the respondents also expressed ready to attend the practical accounting training. They who stated very willing is 100 people, or $100 \%$. Practical knowledge of accounting is important since in the future they can record their efforts to develop their business transactions, and can make clear and simple financial statements.

From this descriptive study we can conclude that the approach to poverty alleviation is actually more efficient if done by giving a fishing pole than a fish. Many social assistance given by the government through various institutions established without the development of the entrepreneurship attitude finally failed. Based on data from the Central Statistics Agency (BPS, 2000), the percentage of poor people in Indonesia in 1996 is still very high at 17.5 percent or 34.5 million people. This is in opposition to the view of many economists who claim that high economic growth can increase people's income and ultimately reduce poverty. Government attention to poverty reduction in government reform looks bigger aftermath of the economic crisis in mid-1997. Nonetheless, based on the calculation of the BPS, the percentage of poor people in Indonesia until 2003 remained high, at 17.4 percent with a larger population, namely 37.4 million people. In fact, according to figures of the National Family Planning Coordinating Board (BKKBN) in 2001, the percentage of poor families (and under-prosperous families and prosperous families I) in 2001 reached 52.07 percent, or more than half of the families in Indonesia. These figures indicate that poverty reduction programs has not succeeded to overcome the problem of poverty in Indonesia. Basically there are two important factors that could cause the failure of poverty alleviation programs in Indonesia. First, poverty alleviation programs have tended to focus on the distribution of social assistance 
for the poor. It was, among others, in the form of rice for the poor and the social safety net (JPS) to the poor. Efforts like this will be difficult to resolve the existing problems of poverty due to the nature of aid is not empowerment, it can even lead to dependence. Assistance programs oriented government 's generosity can actually exacerbate the moral and behavior of the poor. Assistance programs for the poor should be more focused to develop culture and were able to free the productive economic dependence permanent residents. On the other hand, social assistance programs can also lead to corruption in the distribution. It would be better if the funds are directly used to improve the quality of human resources, such as the free school fees, such as elementary school (SD) and junior high school (SMP), as well as free costs of treatment at community health centers (puskesmas). The second factor that can lead to failure of poverty alleviation programs is the lack of understanding of the various parties about the causes of poverty itself so that development programs that exist are not based on issues of poverty, the causes vary locally. As known, the data and information used for poverty reduction programs over the years is the result of macro data of the National Social and Economic Survey (Susenas) by BPS and micro data registration results under-prosperous families and prosperous families I by BKKBN. Both of these data are basically intended for the benefit of a centralized national planning, with emphasis on the uniformity assumption and focus on impact indicators. In fact, the data and information like this is not going to be able to reflect the level of diversity and complexity that exist in Indonesia as a country that covers a lot of areas that are very different, both in terms of ecology, social organization, cultural properties, as well as the prevailing economic forms locally. It could happen that the poverty figures are not realistic for local interests, and can even confuse local government (district/city).

In this framework the empowerment of communities, especially orphanage children should be conducted with the stress on :

a. Creating an atmosphere or climate that allows the development potential or community-owned power (enabling). Here the starting point is the recognition that every human being, every society has the potential to be developed. Empowerment is an attempt to build the power, by encouraging (encourage), to motivate and raise awareness (awareness) to its potential, and seeks to develop it.

b. Potential or strengthen community-owned power (empowerment) through the provision of financial assistance in the form of inputs, infrastructure development, both physical (roads, irrigation, electricity) and social (education, health), as well as development funding agencies, research and marketing in the Region, and the opening of access to the various opportunities that would make people become more empowered.

c. Empowerment also contains the meaning of protecting the public through the weak side with the community to prevent an unbalanced competition because the weak faces the strong, and it does not mean isolating or covering of interaction. Community empowerment does not make people dependent on a variety of programs giving (charity), because basically every what is enjoyed is what must be produced on one's own account, the results of which can be exchanged with other parties .

\section{CONCLUSION}

From the result of research and discussion that has been presented, it can be concluded the following:

1. From the aspect of respondents' characteristic, it is found out that respondents with male gender are 77 people and female are 23 people. This means that until now orphanage in the city of Malang that accommodate more boys. It is also known that orphanage children who have just father is 53 or $53 \%$, of which only have mother is 29 children or $29 \%$, whereas the orphan status or who do not have a father and mother is 18 children, or $18 \%$. This means 
need much external help to empower them so that one day when they are out of the orphanage they can be more independent. Besides, in fact the orphans in the orphanage Malang have various place of origin, not only from Malang. From Malang city is 54 people or $54 \%$, East Java is around 12 people or $12 \%$ and from outside East Java is 9 or $9 \%$ and from outside Java especially from Eastern Indonesia is 25 people or $25 \%$. The level of education of orphanage children is SMTA/SMK/MA level, for sampling technique applied is purposive sampling. Most of orphanage children having no education and training for entrepreneurship is about 75 people or $75 \%$, while the already attended training about 25 people or $25 \%$.

2. From the aspect of respondents' real need, the number of respondents expressed deeply need knowledge of entrepreneurship are 85 people or $85 \%$, which need are 15 people or $15 \%$. Orphanage children also expressed highly in need of entrepreneurship education and training is 100 people or $100 \%$ thus entrepreneurship training for orphans is important to implement, to prepare for the future when they have graduated from high school (SMTA) and had not lived anymore within the orphanage. It is found that the respondents who stated need deeply business design knowledge is 74 or $74 \%$ and the stated need is 26 people or 26 $\%$. On the other hand respondents feel believe so much that by attending the entrepreneurship education and training will improve their entrepreneurship ability is 72 or $72 \%$, and the ones who believe is 28 or $28 \%$. The respondents also stated that approximately 95 respondents or $95 \%$ said believe so much that attending business design training can improve their entrepreneurship ability, while those who believe is 5 or $5 \%$. After the training of the respondents also expressed eager to follow the post-training business consultation. This business consultation includes a business design, how to start opening a business, how dealing with supplier, how the policy of pricing, how to promote, how to deal with banks etc. They who very ready are 100 people or $100 \%$. Besides, the respondents also expressed ready to attend the practical accounting training. They who stated very willing is 100 people, or $100 \%$. Practical knowledge of accounting is important since in the future they can record their efforts to develop their business transactions, and can make clear and simple financial statements.

3. There should be a follow-up of this study namely to design a form of entrepreneurship training model so it can be used as a vehicle to educate orphanage children in order to be ready to become entrepreneurs when going back into the community.

\section{BIBLIOGRAPHY}

Agpalo, Remigio, E., (2006) Modernization, Development, and Civilization: Reflections on the Prospects of Political Systems in the First, Second and third Worlds

Kenneth E. Bauzon (ed),Development and Democratisation in the Third World: Myths, Hopes and Realities; Washington: Crane Russak

Asngari, Pang S. (2003), Komunikasi, Informasi dan edukasi dalam penyuluhan Pembangunan, Fakultas Peternakan, IPB, Bogor.

Azis, Iwan Jaya. Kesenjangan Antara Ekonomi Makro dan Gejala Mikro: Keterbatasan Ilmu Ekonomi? Pidato Pengukuhan Jabatan Guru Besar Tetap

Dalam Ilmu Ekonomi padaFakultas Ekonomi Universitas Indonesia. Jakarta, 29 Februari 1996. 
Badan Perencanaan Pembangunan Nasional (2003) "Kebijakan Strategis Pemberdayaan Masyarakat"

Bambang Ismawan \& Setyo Budiantoro (2005), Kemiskinan dan Pemberdayaan, dalam Pembendayaan tak pernah berhenti, Catatan dan Refleksi

dompet dhuafa, Penerbit Khairui bayan Press

Badan Pusat Statistik, 2000, Data tentang tingkat kemiskinan dan pengangguran di Indonesia, jakarta. BPPS

Brown, Donald. (2005) "Poverty-Growth Dichotomy”. Uner Kirdar dan Leonard Silk (eds.), People: FromImpoverishment to Empowerment. New York: New York University Press.

Dinas Infokom. Jatim.2001. Profil Jatim (online). (http: //www.d.Infokom-Jatim).

GERDUTASKIN Propinsi Jawa Timur, 2004, Program Pemberdayaan Petani di Wilayah Malang Raya, BAPEDA JATIM

Dwivedi, Anju (2006), Merancang Pelatihan Partisipatif Untuk Pemberdayaan, Metodologi Pelatihan Partisipatif, Terjemahan Bebas dari Buku Methode of Participatory Training, Penerbit Pondok Edukasi, Yogjakarta.

Friedman, John, (2002) Empowerment: The Politics of Alternative Development. Cambridge: Blackwell,

Josephine, Wuri (2005), UKM danPerannya dalam Menanggulangi Kemiskinan, Reposisi Usaha Mikro Kecil Dan Menengah Dalam Perekonamian Nasional, Penerbit Universitas Sanata Dharma, Yogjakarta.

Islam, Syamsul, (2010) Model Akreditasi Panti Asuhan, Majelis Kesehatan Pimpinan Wilayah Muhammadiyah Jawa Timur, Surabaya

Karsidi, Rafik (1999), Kqjian Keberhasilan Transformasi Pekerjaan dari Petani Ke Pengrajin Industri Kecil, Disertasi Institut Pertanian Bogor.

Kartasasmita Ginanjar, (1995) Pembinaan Program dan Pendampingan Pokmas IDT; Jakarta: Badan Perencanaan Pembangunan Nasional - Departemen Dalam Negeri, 1995.

Kartasasmita, Ginandjar, (1995) Ekonomi Rakyat: Memadukan Pertumbuhan dan Pemerataan; Jakarta: CIDES, 1995.

Kartasasmita, G., Pembangunan Menuju Bangsa yang Maju dan Mandiri: Sebuah Tinjauan Mengenai Berbagai Paradigma, Problematika, dan Peran Birokrasi dalam Pembangunan; PidatoPenerimaan Penganugerahan Gelar Doctor Honoris Causa Dalam Ilmu Administrasi Pembangunan dari Universitas Gajah Mada, Yogyakarta, 15 April 1995.

Kartasasmita G., Pemberdayaan Masyarakat: Sebuah Tinjauan Administrasi; Pidato Pengukuhan Jabatan Guru Besar dalam Ilmu Administrasi pada Fakultas Ilmu 
Administrasi Pemangunan Universitas Brawijaya; Malang, 27 Mei 1995.

Kenneth E. Bauzon (ed), Development and Democratisation in the Third World:

Marcus A. (2005), Yogendra Prosad Acharya,Local Culture, Local Power: Micro finance in Rural Nepal, Working Paper No. 01/05, 2005, Melbourne University Private.

Nadler, Leonard, 2002, Designing Training Program, The Critical Event Model, Addison Wesley Publishing Company, London.

Sangadji, E.M.(2008) Perancangan Bisnis, Modul Kuliah, pada Jurusan teknik Industri UM, 2008 (Tidak diterbitkan)

Sangadji, E.M. (2008), Pedoman Pengelolaan Pembukuan Usaha Kecil, makalah

disampaikan dalam pelatihan Kewiraushaan, Bagi Pengusaha Muhammadiyah se Malang raya, Pengurus Majelis Ekonomi Muhammadiyah Kota Malang

Setyarso Iqbal donAdhiatmoko Sunaryo (2005), Pemberdayaan Tak Pernah

Berhenti Catatan dan Refleksi Dompet Dhuafa, Khairul Bayan Press, Jakarta Selatan.

Slamet, Margono (2003), "Pemberdayaan Masyarakat", dalam Membentuk Pola Perilaku Manusia Pembanganan, Disunting oleh Ida Yustina dan Adjad Sudrajat, Bogor : IPB Press.

Swasono, Sri-Edi (2003), "Kemandirian dasar Martabat bangsa", Pidato ilmiah dalam Rangka Diesnatalis Universitas Gajayana Malang, September 2003

Sasono, Adi, 2003, Pemberdayaan Tanpa akhir Terhadap Petani Melalui Koperasi, Makalah, KOPINDO Jakarta.

Simanowitsz, Anton and Alice Walter (2002), "Ensuring Impact: Researchingthe Poorest while Building Financially Self-Sufficient Institutions, and Showing Improvement in the Live of the Poorest Women and Their Families", In Sam Daley-Harris Pathways out of Poverty, Kumarian Press, Inc., Biaomfield, CT.

Suharto Edi (2005),Membangun Masyarakat Memberdayakan Rakryat, kajian Integral Pembangunan Kesejahteraan sosial dan Pekerjaan Sosial, Refika Aditama, Jakarta

Sulistyowati, Firma (2005), Pengembangan Lembaga Kredit Mikro yang berperspektif Gender, Reposisi Usaha Mikro Kecil Dan menengah Dalam Perekonomian

Tumasz A. Duff y (2005), Credit and Co-Wives: Exploring Empowerment In Senegal, College of Arts and Sciences CUREJ- College Under Gradute Research Electronics Journal University of Pensyilvania. 